\title{
Evaluation of the Effectiveness of Authentic Assessment on Students' Attitudes
}

\author{
Sabtiawan ${ }^{1)}$ \\ Yuanita ${ }^{2)}$ \\ Rahayu ${ }^{3)}$ \\ ${ }^{1)}$ Postgraduate student of Science Education Program, Universitas Negeri Surabaya \\ ${ }^{2)}$ Professor at Chemistry Department, Mathematics and Natural Sciences Faculty, Universitas Negeri Surabaya \\ ${ }^{3)}$ Doctor at Biology Department, Mathematics and Natural Sciences Faculty, Universitas Negeri Surabaya \\ e-mail:wahyusabtiawan@gmail.com
}

\begin{abstract}
This study aimed to evaluate the effectiveness of using the authentic assessment on students' attitudes involving interest and enjoyment when they learned Atomic Absorption Spectroscopy Topic. Selected sample of this research was 37 students of chemistry who enrolled in the Spectroscopic Methods of Analysis Subject, Mathematics and Natural Sciences Faculty, The State University of Surabaya. This research was conducted by using case study research. The data were gained through two techniques, namely, observation and interview, and were analyzed using descriptive qualitative. The findings informed that the students showed positive feelings toward the topic after and during learning constructed by using authentic assessment dimensions with embedded cooperative learning syntax, especially student's interest and enjoyment. They felt interested to the topic because of three reasons, that are, learning the theory through practice, discussion intensively, and activity like the real workplace. Moreover, they enjoyed during the learning because of four reasons also, that are, discussion without reluctance, no forcing all concept at once, synchronizing between theory and practice occurring well, and learning in a team. In conclusion, the learning constructed through the authentic assessment dimensions was effective to foster students' attitudes.
\end{abstract}

Keywords: Authentic assessment, students' attitudes, student's interest, student's enjoyment.

\begin{abstract}
Abstrak: belajar mahasiswa meliputi aspek student's interest dan enjoyment pada Mata Kuliah Metode Spektroskopi Analisis (Analitik III). Subjek penelitian ini adalah 37 mahasiswa kimia yang memprogram Mata Kuliah Analitik III di FMIPA-UNESA. Penelitian ini dilakukan menggunakan desain studi kasus yang mana teknik pengambilan data dilakukan melalui observasi dan interview. Data yang diperoleh menunjukkan respon positif selama pembelajaran (pembelajaran yang dirancang menggunakan dimensi-dimensi penilaian otentik) pada mata kuliah ini. Mereka merasa tertarik (student's interest) belajar pada topik yang mereka pelajari karena tiga alasan yaitu belajar teori melalui praktik, diskusi secara intensif dan aktifitas seperti seorang profesional. Kesenangan belajar (student's enjoyment) timbul karena empat hal, antara lain adanya diskusi, tidak dipaksa memahami semua konsep pada satu kali pertemuan, adanya integrasi yang baik antara teori dan praktek dan belajar dalam kelompok. Dengan demikian, dapat disimpulkan bahwa penilaian otentik efektif untuk menimbulkan dan mendorong sikap belajar mahasiwa.
\end{abstract}

Kata kunci: Penilaian otentik, sikap belajar, student's interest, student's enjoyment

\section{Introduction}

Many educators in Indonesia have been still using an assessment only for "assessment of learning". In other words, they are still using traditional assessment. Traditional assessment dominantly assesses students based on test items that have one right answers (Herrington \& Herrington, 2006) so that they will tend to memorize the materials taught in their lesson. As a result, it fails to improve students' abilities to perform "real world" task and also student's attitudes. Furthermore relating to the student's attitudes, the traditional assessment is capable to decrease the motivation, interest even enjoyment of students. As in Taylor and Nolen (2005, p.7), students may lose motivation for learning if there is mismatch between school and the world beyond school.
It can be said that the important one is not only student's performance but also student's attitudes. According to several researchers (Ainley, Hidi, \& Berndorf, 2002; pintrich, 2003; schraw \& Lehman,

2001), greater the feelings tend to more positive emotional responses to the material, then greater persistence, deeper processing, better remembering of the material, and higher achievement. In other words, the student's attitudes are able to affect student's performance. There is an assessment that is able to facilitate in term of promoting student's attitude, namely, authentic assessment. It is a method that needs students to integrate attitudes to their knowledge and skills as professional need in the real world (Gulikers, Bastiaens, Kirschner and Kester, 2006). The authentic assessment has five 
dimensions to represent its authenticity, that is, task, physical context, social context, assessment result or form and criteria (Gulikers, Bastiaens, \& Kirschner 2004). Through the dimensions, the learning will be constructed and hoped to promote student's attitudes. Therefore, this study will evaluate the effectiveness of authentic assessment on student's attitudes especially student's interest and enjoyment.

\section{Research Method}

\section{A. Research Subjects}

The research subject is one undergraduate chemistry class of chemistry department of UNESA involved 37 students still programming Spectroscopic Methods of Analysis subject.

\section{B. Research Design}

This study applied a case study design to examine the research questions. The case study refers to an approach to research that facilitates exploration of a phenomenon in real setting or its context using multiple data sources (Baxter and Jack, 2008).

\section{Time and Place of Research}

The research was held during a semester in 2013 , Chemistry Department, Mathematics and Natural Sciences, UNESA.

\section{Technique of Data Collection}

This research used several ways to collect the data so that the researcher has quantitative data and qualitative data. The quantitative data were obtained through observation while the qualitative data were yielded through observation and interview.

\section{E. Technique of Data Analysis}

Student's attitudes were also analysed by using descriptive qualitative technique. This analysis focused on student's interest and enjoyment. The researcher analysed how far student's interest and enjoyment during implementation of authentic assessment based on the data from observation and interview. The researcher provided comments on students' activities and statements.

\section{Results and Discussion}

To examine the investigation that relates to student's attitudes toward learning the topic during the implementation of authentic assessment in more elaboration, it will be used three sources, that are, student's perspective through result of interview, research perspective through research diary based on the real condition, and the result of affective abilities observation. This discussion of student's attitudes will be only focused on interest and enjoyment.

\section{A. Analysis of Student's Interest Toward Learning the}

Topic After the Implementation of Authentic Assessment

There were several indications that the students are interested toward the learning. The research diary noted that the indications of the student's interest at the phenomenoa below.

"The class also showed good respond when I explained the task. They asked some questions related to the task, seemed had good motivation, and interested enough." (P5)

“... pose questions and ideas without forcing." (P10, P19 \& P23)

The phenomena above are supported by the result of affective abilities observation. The result informed that posing questions and ideas (meeting 3-5) are in the range of good and excellent level. It means that the students are interested toward the topic by showing their good respond. In addition, the result of interview below also supported the student's interest during the learning.

"It was interesting..." (lower performance student) "We were interested to it..." (middle performance student) "We felt interest in this topic..." (higher performance student)

There are three reasons of student's interest based on the result of interview. The first is learning the concept through theory. It was stated by the middle performance student below.

“...we discussed and synchronised it with several aspects (theory and practice).” (middle performance student)

They argued above because they were not only forced to practice directly like a professional but also they were learning the theory or concept to finish the task well. This is the manifestation of first dimension of authentic assessment, that is, authentic task. Therefore, the student's interest was raised through the authentic task.

The second is opportunity to discuss each other intensively as stated by the higher performance student below.

"... we were not boring to listen the lecturing dominantly but we are hoped to active in this learning..." (higher performance student)

The students can stated that reason because of the existence of social context (one of authentic assessment dimension) and the third authentic task characteristic (authentic tasks needs over a sustained period of time (Herrington et al. (2010, p. 46-48)).

Thirdly, their interest was caused by their engaging to the activity like the real work place as stated by 
the lower performance students below.

“... We learned like an analyst so that it was appropriate with our future..." (lower performance student)

The student's reason for their interest rose because the authentic task was provided for the concept learning. Aladejana and Aderibigbe (2007) explained that laboratory work (real work of analyst) conducted in a good environment is able to promote student curiosity. Therefore, the student's interest will be increasing.

Based on the discussions above, the student's interest toward Atomic Absorption Spectroscopy Topic was promoted because they learned through the learning constructed by using authentic assessment dimensions. In other word, the situational interest was promoted after getting the stimuli.

\section{B. Analysis of Student's Enjoyment During Learning the Topic}

Beside the student's interest, student's enjoyment is also important to give positive feeling toward the learning. The indications of student's enjoyment can be known by using the result of research diary noted at the phenomena 8 , 14, 17, and 21. Moreover, the result of interview strengthens those phenomena as stated below.

"We got the enjoyment during

learning..." (lower performance student)

“... Then, I felt enjoy..." (middle performance student)

"I enjoyed this learning ..." (higher performance student)

Thus, the research diary and interview result are in line that the students enjoyed the learning during the authentic assessment is implemented.

There are three reasons behind the perspective of student's enjoyment. First, the reason stated from the higher performance students below.

"... I could share information with my friends in a group and other groups without reluctance." (higher performance student)

Their statement above informs that their experience in term of discussion with others can promote their enjoyment. According to them, the something different is that they had more opportunity to share their known or unknown each other without reluctance. Their enjoyment during discussion is also noted in the research diary below.

"Each group presented their design and they discussed each other. During discussion, they seemed to start enjoying their learning because they shared information to each other without reluctance." (P8)

"Each group presented their draft and they discussed each other. During discussion, they seemed to start enjoying their learning because they shared information to each other without reluctance." (P17)

"Each group presented their final report and they discussed each other. During discussion, they seemed to start enjoying their learning because they shared information to each other without reluctance." (P21)

Every student had more opportunity to discuss each other because of the implementation of learning syntax constructed by using the authentic dimensions.

Second, the enjoyment of student was arisen because they were not forced to master the concept at short time. This perspective describes the success of an authentic task characteristic proposed by Herrington et al. (2010, p. 4648). It is that authentic tasks needs over a sustained period of time. Hence, the students were able to learn the topic with their enjoyment and without burden or forcing their capability. Third, the perspective comes from the lower performance students as stated below.

“... there was synchronised between theory and practice so that it was unforgettable." (lower performance student)

The students did not need to learn the theory and practice separately. Based on those, it can be argued that the students felt enjoy because they could synchronize between the theory and practice easily without separate both. In addition, this aspect also relates to the laboratory activity. As noted in the research diary below

"The learning condition in the laboratory tended to noisy but they seemed enjoy their practicum." (P14)

Likewise, Hofstein and Lunetta (2003) argued that students' attitudes move towards positive states when the teacher using laboratory activities to enhance the teaching. Therefore, based on this third perspective, the authentic task was able to facilitate the enjoyment of student during learning of AAS topic.

Fourth, the middle performance students purposed that they got the enjoyment because they learned in a team as stated below.

“... I felt enjoy because we learned in a team." (middle performance students)

Wentzel explanation as cited in McInerney and McInerney (2010, p. 247), the social interaction in teams can result good behavior among teammates. In other 
words, interaction and supporting each other between teammates will strengthen the relationship between them. Especially, growing the good relationship between less and more capable students is one of the important purposes of learning in a team. Hence, if the good relationship was formed successfully, the enjoyment of learning in a team will be gotten by the students.

In summary, the student's attitudes involving interest and enjoyment are promoted toward the learning of Atomic Absorption Spectroscopy Topic. The learning environment is the main factor for the student's interest and enjoyment. Therefore, the authentic assessment dimensions constructed the learning environment is appropriate for the students who are learning Atomic Absorption Spectroscopy Topic.

\section{CLOSURE}

\section{Conclusion}

In conclusion, the learning constructed through the authentic assessment dimensions was effective to foster student's attitudes positively. The students showed their interest and enjoyment toward the topic after and during learning constructed by using authentic assessment dimensions with embedded cooperative learning syntax.

\section{Suggestion}

There are three suggestions that will be proposed to this research and further research. They are stated below.

a. The student's confuse and stress at the first moment will be able to be minimized by optimizing the phase 1 of cooperative learning syntax.

b. The student should be provided more information about the role of this topic for their future, such as providing video about AAS for increasing the student's motivation in the first moment.

c. For the research conducted in small laboratory. The condition of laboratory during student's experiment should be arranged in better way for minimizing the crowded condition.

\section{REFERENCES}

Aladejana, F., \& Aderibigbe, O. 2007. "Science laboratory environment and academic performance". Journal of Science Educational Technology, Vol. 16, pp. 500506.

Ainley, M., Hidi, S. and Berndorf, D. 2002. "Interest, learning, and the psychological processes that mediate their relationship". Journal of Educational Psychology, Vol 94, pp. 545-561.

Baxter, P. \& Jack, S. 2008. "Qualitative case study methodology: Study design and implementation for novice researchers". The Qualitative Report, Vol.
13 No. 4, pp. 544-559.

Gulikers, J.T.M., Bastiaens, T.J., Kirschner, P.A. 2004. “A five- dimensional framework for authentic assessment". Educational Technology Research and Development, Vol. 52 No. 3, pp. 67-86.

Gulikers, J.T.M., Bastiaens, T.J., Kirschener, P.A., \& Kester, L.

2006. "Relations between student perceptions of assessment authenticity, study approaches and learning outcome". Studies in Educational Evaluation, Vol. 32, pp. 381400.

Herrington, A., \& Herrington, J. 2006. "What is an authentic learning environment?" In T. Herrington and J. Herrington (Ed). Authentic learning environment in higher education, 48-60. Hersey, USA: Information Science Publishing.

Herrington, J., Reeves, T.C., \& Oliver, R. 2010. A guide to authentic e-learning. UK: Routledge.

Hofstein, A. \& Lunetta, V. N. 2003. "The Laboratory in Science Education: Foundations for the Twenty-First Century". Review of Research. Willey Periodicals, Inc.

McInerney, D. M. \& McInerney, V. 2010. Educational Psychology: Constructing Learning. 5th Edition. New South Wales: Pearson.

Pintrich, P. R. 2003. "A motivational science perspective on the role of student motivation in learning and teaching". Journal of Educational psychology, Vol. 95, pp. 667-686.

Schraw, G. and Lehman, S. 2001. "Situational interest: A review of the literature and directions for future research". Educational Psychology Review, Vol. 13, pp. 23-52.

Taylor, C.S., \& Nolen, S.B. 2005. Classroom assessment: Supporting teaching. 